\title{
Knowledge and Attitudes of Coaches Regarding Sports Related Oro-facial Injuries in Chennai, India
}

Priya M, Ditto Sharmin ${ }^{*}$, Deepti Amarlal, Eapen Thomas and Pooja Y

Department of Pediatric and Preventive Dentistry, Meenakshi Ammal Dental College and Hospital, Chennai, Tamilnadu, India

*Corresponding author: Ditto Sharmin, Department of Pediatric and Preventive Dentistry, Meenakshi Ammal Dental College and Hospital, Chennai, Tamilnadu, India, Tel: +91 9486190456; Fax: +91 44 23781631; E-mail: dr.dittosharmin@gmail.com

Rec date: May 18, 2016; Acc date: June 04, 2016; Pub date: June 13, 2016

Copyright: (c) 2016 Priya M, et al. This is an open-access article distributed under the terms of the Creative Commons Attribution License, which permits unrestricted use, distribution, and reproduction in any medium, provided the original author and source are credited.

\begin{abstract}
Aim: The aim of this study was to assess the knowledge and attitudes of sports coaches regarding sports related injuries and its prevention using a questionnaire survey design.

Material and Methods: A modified questionnaire was distributed to 50 coaches of various sports teams in different parts of Chennai city in India between October 2009 and February 2010. The statistical analyses were carried out by SPSS version 18.0 and the data were analyzed.

Results: Out of 50 coaches, $94 \%$ were males and $6 \%$ were females with mean age of 38.74 years. $70 \%$ of the coaches found the frequency of injury in the range of $1-5$, which included soft tissue injury (46\%) followed by bruise and dental trauma. $66 \%$ of the coaches believed that boxing was the sports event most likely to cause injury, but boxing, football and rugby (38.5\%) were the sports which actually caused injury. The mechanism of injury was mainly due to collision (42\%). The protective devices most commonly used were helmet $(61.4 \%)$ and mouthguards $(47.7 \%) .70 \%$ of the coaches felt that non-use of protective devices can cause injuries sometimes. $68 \%$ of the coaches found that protective devices enhance the efficiency of the players and $76 \%$ considered the use of protective devices based on the type of games.
\end{abstract}

Conclusions: The results show that there is an increasing acceptance to the use of protective devices among the coaches of Chennai, but its usage was mostly based on the type of game.

Keywords Coaches; Sports injuries; Protective devices

\section{Introduction}

A physically active lifestyle is important for all age groups. Reason to participate in sports and physical activity are many such as pleasure, relaxation, competition, socialization, maintenance and improvement of fitness and health [1]. Participation in sports offers potential benefits for individuals of all ages, such as combating obesity and enhancing cardiovascular fitness. A well-designed exercise program enhances the immediate physical, psychomotor, and intellectual attainments of a child [2]. Thousands of school children play at least one organized sport [3]. It is of growing concern about the injuries that occur during participation in organized sports [4]. Injuries during sport appear to be unavoidable, and up to $30 \%$ to $40 \%$ of all accidents in children and adolescents occur during sports [5]. The prevalence of sports injuries vary widely. Comparing injury statistics can be difficult as there is no uniform system for reporting the number of injuries [6,7].

Contact sports are defined as those sports in which players physically interact with each other, trying to prevent the opposing team or person from winning [8]. There is seldom very high incidence of dental trauma compared with all accidents in contact sports varying from $2 \%$ to $33 \%$ [9-11]. Dental and soft tissue injuries are commonly associated with collision and contact sports such as football, ice hockey, soccer, baseball, bicycling, inline skating, gymnastics, basketball, alpine skiing, softball, volleyball, karate, mountain biking and skateboarding [6,12-16].

Incidence of sports related oral injury vary widely based on the sport played, level of competition, the participant's age and sex $[6,17]$. Dental injuries are the most common type of orofacial injuries sustained during sports activities [18]. Dental trauma in sports differ from other dental trauma, as it is possible to easily prevent it and there is also a possibility to dramatically reduce the occurrence levels by the use of mouthguards that protect all dental and periodontal structures $[19,20]$. Dental professionals have long encouraged mouthguard use and dental consultation in organized sports [21]. The only professional sports that require a mouthguard is boxing [22]. In New Zealand, despite a high incidence of avulsive injuries, sports coaches generally had an inadequate knowledge for managing such conditions [23]. Injuries can counter the beneficial effects of sports participation at a young age if a child or adolescent is unable to participate because of the residual effects of injury [24,25].

Some sports medicine professionals pointed directly to poor coaching as a factor in injury [26]. Many young athletes are never taught the proper conditioning methods or technique for their sports [27], as the coaches simply do not have the proper knowledge base for instructing in correct sports techniques [28]. However Smith and Smoll and Smith et al. proved the effectiveness of certain communication techniques used by coaches to interact with young athletes during their coaching [29-31]. The risks are always inherent 
Page 2 of 4

risks in physical activity hence our goal should be to create a safe environment as possible in which our children can participate.

This present study was undertaken because a thorough search of the literature revealed sparse data of the perception of Indian coaches regarding oro-facial injuries and their prevention. This study evaluated the perception and attitudes of sports coaches in Chennai, India regarding various aspects of sports related oro-facial injuries as they have a direct influence on the trainees. The data collected from the coaches could be utilized to plan a sports injury preventive strategy by providing feedback to coaches, trainees and henceforth promote the use of oro-facial protective devices.

\section{Materials and Methods}

This study is a descriptive survey research design which was carried out between October 2009 and February 2010. The questionnaire which was used in the previous studies on coaches by Lehl [32] was modified and finally 15 open and closed ended questions were structured. The questionnaire was distributed to fifty coaches who assisted with the study after informed consent. The survey was conducted on the various sports teams in different places of Chennai like YMCA, Radha Krishna stadium, Nehru Park and sports authority of India.

The investigators went through this questionnaire with each of the participants separately in order to avoid blanket answers by the entire team of coaches. The questionnaire sought information about what sport(s) they coached, the experience they had as a coach, the rate of oral trauma they had seen during sport activities, the mechanism of injuries, type of injury, various protective devices they knew for each games and its usage in sports to avoid injuries.

\section{Statistical Analysis}

Descriptive statistics such as mean age and SD were carried out Graphic presentation of data using the pie chart was also employed. The statistical analyses were carried out using statistical package for social sciences (SPSS for windows) version 18.0 and the data were analysed as percentages and proportions.

\section{Results}

A total of 50 coaches completed the questionnaire of which $94 \%$ were males and $6 \%$ were females. The mean age of the coaches was 38.74 years. $50 \%$ of the coaches had a Physical Education Training (PET) and $34 \%$ of the coaches had 11 or more years of coaching experience. The games for which coaching was provided is listed in Table 1, which showed that football was most common (20\%). $96 \%$ of the coaches had sports injury prevention as part of their syllabus and $80 \%$ of the coaches had interacted with the medical or dental experts regarding the safety measures in sports.

$70 \%$ of the coaches found the frequency of injury in the range of 1-5 (Table 2). 66\% of the coaches believed that boxing was the sports event most likely to cause oro-facial injury. Boxing again stood first among the sports events (38.5\%) along with football and rugby which actually caused injury. In majority of the injuries, the mechanism by which they were caused was due to collision (42\%). The most common injury was a soft tissue injury (46\%) like cut lip, cheek or tongue, followed by bruise and dental trauma. $46.20 \%$ of the coaches gave first aid by themselves.

\begin{tabular}{|l|l|l|}
\hline $\begin{array}{l}\text { Games for which now } \\
\text { coaching is provided }\end{array}$ & Frequency & Percentage \\
\hline Athletics & 4 & $8 \%$ \\
\hline Basket ball & 5 & $10 \%$ \\
\hline Boxing & 3 & $6 \%$ \\
\hline Cricket & 8 & $16 \%$ \\
\hline Foot ball & 10 & $20 \%$ \\
\hline Hockey & 5 & $10 \%$ \\
\hline Kabbadi & 3 & $6 \%$ \\
\hline Kho-kho & 3 & $6 \%$ \\
\hline Rugby & 4 & $8 \%$ \\
\hline Volleyball & 5 & $10 \%$ \\
\hline Total & 50 & $100 \%$ \\
\hline
\end{tabular}

Table 1: Games for which coaching is provided

\begin{tabular}{|l|l|l|}
\hline $\begin{array}{l}\text { Frequency of sustaining } \\
\text { an injury }\end{array}$ & Frequency & Percentage \\
\hline None & 11 & $22 \%$ \\
\hline 5-Jan & 35 & $70 \%$ \\
\hline 6 or more & 4 & $8 \%$ \\
\hline Total & 50 & $100 \%$ \\
\hline
\end{tabular}

Table 2: Frequency of sustaining an oro-facial or dental injury under respondent's coaching

On comparing the games and protective devices used, $31.4 \%$ of the coaches opted mouthguard as the most preferred protective device for boxing. Helmet was the most preferred protective device for cricket (49\%) and hockey (40\%). In games like football, rugby and others, the most preferred protective devices opted was from the other's category which includes shinguard, abdomenguard etc.

\begin{tabular}{|l|l|l|}
\hline Frequency of injury & Frequency & Percentage \\
\hline Always & 14 & $28 \%$ \\
\hline Sometimes & 35 & $70 \%$ \\
\hline Never & 1 & $2 \%$ \\
\hline Total & 50 & $100 \%$ \\
\hline
\end{tabular}

Table 3: Frequency of oro-facial injury when not using protective devices

The frequency of injuries when not using protective devices is shown in Table 3 . Of which $70 \%$ of the coaches felt that non-use of protective devices can cause injuries sometimes and $28 \%$ of the coaches felt that non-use of protective devices can cause injuries always. $68 \%$ of the coaches found that protective devices enhance the efficiency of the players and $76 \%$ of the coaches considered the use of protective devices based on the type of games. Out of 50 coaches only 
24 coaches responded for protective devices other than mouthguard, helmet, facemask and knee cap (Table 4).

\begin{tabular}{|l|l|l|}
\hline \multirow{2}{*}{ Other Protective devices } & \multicolumn{2}{l|}{ Responses } \\
\cline { 2 - 4 } & N & Percent \\
\hline Shinguard & 9 & 37.5 \\
\hline Head Gear & 2 & 8.3 \\
\hline Abdomenguards & 1 & 4.2 \\
\hline Armguards & 2 & 8.3 \\
\hline Elbowcap & 3 & 12.5 \\
\hline Kneecap & 1 & 4.2 \\
\hline Crapbandage & 3 & 12.5 \\
\hline Boot / spikes & 3 & 12.5 \\
\hline Total & 24 & 100 \\
\hline *(Out of 50 persons only 24 have answered for this question) \\
\hline
\end{tabular}

Table 4: Other protective devices other than mouth guards (Multiple answers)

\section{Discussion}

Injury has always been recognized as a natural risk of participation in organized sport. However, many injuries may be preventable, particularly those resulting from a lack of proper, well-supervised training and participation. The present study focused on the knowledge and attitudes of coaches regarding oro-facial injuries and their prevention since they are the main influence on athletes. $70 \%$ of the coaches in the present study found the frequency of oro-facial injuries between 1-5 and 70\% of these injuries were mostly due to nonuse of protective devices. In a similar study by Lehl, $40 \%$ of the coaches found the frequency of injury between 1-5 [32]. Authors who found the frequency of injury due to non-use of protective devices were $82 \%$ by Lehl, $63 \%$ by Garon et al., $75 \%$ by Mc Nutt et al. and $48 \%$ by Rob Berg et al. [32-35].

Though $66 \%$ of the coaches in the present study believed that boxing most likely caused injury, the sports events that actually caused injury along with boxing (39\%) were also football (39\%) and rugby (39\%). This may be because probably higher percentage of coaches were having football as their main sport (20\%). Similar results were also found by Mc Nutt et al. and Garon et al. who found the highest oro-facial injuries with football $[33,34]$. According to Fos et al. the high velocity and intensity of football, hockey and rugby place them in a high risk category for oro-facial injuries whereas Kujala et al. observed that injury rates were higher in those sports involving more frequent and powerful body contact like ice hockey and karate [36,37].

In the present study, majority of the injuries occurred due to collision (42\%) followed by hit by an object (32\%). The most common type of injury were soft tissue injuries (46\%) followed by bruising (24\%) and dental trauma (16\%). In a similar study, Blinkhorn found that falls and collision were the main cause of injury [38]. Rob Berg et al. found in his study that the most common injury was a cut lip, tongue or cheek (82.4\%). He also suggested that this type of injury should be a cause for great concern, as they may represent a tooth- object impact in which significant tooth damage was avoided only fortuitously.

The protective devices most often preferred by the coaches in the present study were helmet and mouthguards similar to the results by Lehl. Ranalli observed that appropriate and properly fitted protective mouthguards, headgear and helmets prevent oro-facial trauma [39]. Helmets and facemasks when used properly enhance player safety and reduce morbidity [40]. It is a promising finding that $80 \%$ of the coaches had interacted with medical or dental experts regarding injury prevention and $68 \%$ of the coaches found that protective devices enhance the efficiency of the players.

\section{Conclusion}

This study identified several important perceptions and knowledge of the coaches in Chennai, India, regarding sports related injury and the usage of various protective devices. Majority of the coaches indicated that they were aware that their trainees were at risk of experiencing oro-facial injuries, including soft tissue injury and dental trauma. It appears that there is an increasing acceptance to the use of protective devices among coaches but its usage was mostly based on the type of game. We feel that preventable injuries do continue to occur since not all players comply with rules, and not all coaches insist that players wear protective devices during practice and in competition. We recommend that the dentist not only involve themselves in giving adequate information to coaches about protective devices, but also counsel patients, especially children, adolescents and young adults, regarding participation in sports so that adequate oral protection can be recommended.

\section{References}

1. Bahr R, Holme I (2003) Risk factors for sports injuries-a methodological approach. Br J Sports Med 37: 384-392.

2. Shephard RJ (1984) Physical activity and child health. Sports Med 1: 205-233.

3. Nowjack-Raymer RE, Gift HC (1996) Use of mouthguards and headgear in organized sports by school-aged children. Public Health Rep 111: $82-86$.

4. Micheli LJ (1990) Sportswise: an essential guide for young athletes, parents, and coaches. Boston MA: Houghton Mifflin Company.

5. Smith AD, Tao SS (1995) Knee injuries in young athletes. Clin Sports Med 14: 629-650.

6. Kumamoto DP, Maeda Y (2004) A literature review of sports-related orofacial trauma. Gen Dent 52:270-281.

7. Tesini DA, Soporowski NJ (2000) Epidemiology of orofacial sportsrelated injuries. Dent Clin North Am 44: 1-18.

8. Dorney B (1998) Dental screening for rugby players in New South Wales, Australia. FDI World 7: 10-13.

9. Roaas A, Nilsson S (1979) Major injuries in Norwegian football. Br J Sports Med 13: 3-5.

10. Pritchett JW (1981) Cost of high school soccer injuries. Am J Sports Med 9: 64-66.

11. No authors (1994) Football injuries of the head and neck. National Health and Medical Research Council, The Australian Government Publishing Services pp: 121-128.

12. Soporowski NJ, Tesini DA, Weiss AI (1994) Survey of orofacial sportsrelated injuries. J Mass Dent Soc 43: 16-20.

13. Bayliss T, Bedi R (1996) Oral, maxillofacial and general injuries in gymnasts. Injury 27: 353-354. 
Citation: Priya M, Sharmin D, Amarlal D, Thomas E, Pooja Y (2016) Knowledge and Attitudes of Coaches Regarding Sports Related Oro-facial Injuries in Chennai, India. Dentistry 6: 383. doi:10.4172/2161-1122.1000383

Page 4 of 4

14. Maestrello-de Moya M, Primrosch R (1989) Orofacial trauma and mouth protector wear among high school varsity basket-ball players. J Dent Child 56: 36-39.

15. Gassner R, Vasquez Garcia J, Leja W, Stainer M (2000) Traumatic dental injuries and Alpine skiing. Endod Dent Traumatol 16: 122-127.

16. Lang B, Pohl Y, Filippi A (2002) Knowledge and prevention of dental trauma in team handball in Switzerland and Germany. Dent Traumatol 18: 329-334.

17. Bijur PE, Trumble A, Harel Y, Overpeck MD, Jones D, et al. (1995) Sports and recreation injuries in US children and adolescents. Arch Pediatr Adolesc Med 149: 1009-1016.

18. Scott J, Burke FJ, Watts DC (1994) A review of dental injuries and the use of mouthguards in contact team sports. Br Dent J 176: 310-314.

19. Andreasen JO, Andreasen FM, Andersson L (1994) Textbook and color atlas of traumatic injuries to the teeth, 3rd ed. Munksgaard, Copenhagen 719-735.

20. Kerr IL (1986) Mouth guards for the prevention of injuries in contact sports. Sports Med 3: 415-427.

21. Powers JM, Godwin WC, Heintz WD (1984) Mouth protectors and sports team dentists. Bureau of Health Education and Audiovisual Services, Council on Dental Materials, Instruments, and Equipment. J Am Dent Assoc 109: 84-87.

22. Ranalli DN (1991) Prevention of craniofacial injuries in football. Dent Clin North Am 35: 627-645.

23. Stokes AN, Anderson HK, Cowan TM (1992) Lay and professional knowledge of methods for emergency management of avulsed teeth. Endod Dent Traumatol 8: 160-162.

24. Caine DJ, Maffulli N (2005) Epidemiology of children's individual sports injuries. An important area of medicine and sport science research. Med Sports Sci 48: 1-7.

25. Erlandson MC, Sherar LB, Mirwald RL, Maffulli N, Baxter-Jones AD (2008) Growth and maturation of adolescent female gymnasts, swimmers, and tennis players. Med Sci Sports Exerc 40: 34-42.

26. Murphy P (1985) Youth sports coaches: using hunches to fill a blank page. Physician Sportsmed 13: 136-142.

27. Micheli LJ (1995) Sports injuries in children and adolescents. Questions and controversies. Clin Sports Med 14: 727-745.
28. Quain RJ (1989) An overview of youth coaching certification programs. Adolescence 24: 541-547.

29. Smith RE, Smoll FL (1990) Self-esteem and children's reactions to youth sports coaching behaviors: A field study of self-enhancement processes. Dev Psychol 26: 987-993.

30. Smith RE, Smoll FL, Curtis B (1978) Coaching behaviors in Little League baseball. Washington, DC: Hemisphere pp:173-201.

31. Smith RE, Smoll FL, Curtis B (1979) Coach effectiveness training a cognitive behavioral approach to enhancing relationship skills in youth sport coaches. J Sport Psychol 1: 59-75.

32. Lehl G (2005) Perceptions of Chandigarh sports coaches regarding orofacial injuries and their prevention. J Indian Soc Pedod Prev Dent 23: 67-70.

33. Garon MW, Merkle A, Wright JT (1986) Mouth protectors and oral trauma: a study of adolescent football players. JADA 112: 663-665.

34. McNutt T, Shannon SW Jr, Wright JT, Feinstein RA (1989) Oral trauma in adolescent athletes: a study of mouth protectors. Pediatr Dent 11: 209-213.

35. Berg R, Berkey DB, Tang JM, Altman DS, Londeree KA (1998) Knowledge and attitudes of Arizona high-school coaches regarding oralfacial injuries and mouthguard use among athletes. JADA 129: 1425-1432.

36. Fos PJ, Pinkham JR, Ranalli DN (2000) Prediction of sports related dental traumatic injuries. Dent Clin North Am 44: 19-33.

37. Kujala UM, Taimela S, Antti-Poika I, Orava S, Tuomian R, et al. (1995) Acute injuries in soccer, ice hockey, volleyball, basketball, judo and karate: Analysis of national registry data. BMJ 311: 1465-1469.

38. Blinkhorn FA (2000) The aetiology of dento-alveolar injuries and factors influencing attendance for emergency care of adolescents in the North West of England. Endod Dent Traumatol 16: 162-165.

39. Ranalli DN (2000) Prevention of sports-related traumatic dental injuries. Dent Clin North Am 44: 35-51.

40. Rontal E, Rontal M (1971) Maxillofacial injuries in football players: an evaluation of current facial protection. J Sports Med Phys Fitness 11: 241-245. 